\title{
Evaluation of phosphorus bioavailability in sediments of three contrasting lakes in China and the UK
}

\author{
Qixing Zhou ${ }^{\text {a,* }}$, Christopher E. Gibson ${ }^{\text {b }}$, Yinmei Zhu ${ }^{\text {a }}$ \\ a Department of Environmental Sciences, Zhejiang University, Hangzhou 310029, People's Republic of China \\ b Aquatic Sciences Research Division, Department of Agriculture and Rural Development for Northern Ireland, \\ The Queen's University of Belfast, Newforge Lane, Belfast BT9 5PX, UK
}

\begin{abstract}
The bioavailability of phosphorus $(\mathrm{P})$ in sediments from West Lake and Lake Tai (China) and Lough Erne (Northern Ireland) was evaluated using total P (TP), water soluble P (WSP), readily desorbable P (RDP), algal available P (AAP) and Olsen-P. The results indicated that the TP content, the amounts of phosphorus extracted by each method and their proportions to TP varied widely between sediments of the three lakes. TP and chemical extractable phosphorus in the sediments of Lough Erne were considerably higher than those of the two lakes in China. Although TP in the West Lake sediments was similar to that of Lake Tai, the extractable phosphorus data suggested that the bioavailability of $\mathrm{P}$ in West Lake sediments was higher than that in sediments from Lake Tai. Nevertheless, the rank order of extraction efficiency was the same in all lakes and the amount extracted was in the sequence AAP $>$ Olsen-P $>$ WSP $>$ RDP. There was a good correlation between extracted and TP in all the methods examined. (c) 2000 Elsevier Science Ltd. All rights reserved.
\end{abstract}

Keywords: Bioavailability; Chemical extraction; Eutrophication; Fractionation; Lake phosphorus; Potential nutrient release; Sediment

\section{Introduction}

Phosphorus (P) has a predominant role in cellular energetics as ATP and as an important part of many structural and biochemically functional components for cell growth of plants including algae (Gibson, 1971; Hesse, 1971; Dorich et al., 1984). Because it is frequently in a limiting ratio compared to other nutrients, it is also the most important factor in managing lake productivity. Internal loading by sediment release plays a big role in the phosphorus status of some lakes, hence it is important to evaluate the potential for $\mathrm{P}$ release. The potential phosphorus release from sediments to the

\footnotetext{
${ }^{*}$ Corresponding author. Current address: Open Laboratory on Ecological Processes in Terrestrial Ecosystems, Chinese Academy of Sciences, Shenyang 110015, China.

E-mail address: zhouqixing@hotmail.com (Q. Zhou).
}

overlying water and the availability of phosphorus for algal uptake may be better measured by selective chemical extraction methods than by estimating TP (Andrieux and Aminot, 1997; Gibson, 1997; Gonsiorczyk et al., 1998). Early schemes (Chang and Jackson, 1957) partitioned soil phosphorus into labile $\mathrm{P}$, aluminium-bound $\mathrm{P}$, iron-bound $\mathrm{P}$, calcium-bound $\mathrm{P}$, reductant soluble $\mathrm{P}$, occluded $\mathrm{P}$ and organic $\mathrm{P}$ using various chemical extractants. Later work modified the procedure (Williams et al., 1967) and applied the scheme to fractionation of phosphorus in lake sediments (Williams et al., 1971, 1976). With the enrichment of phosphorus in lake sediments, forms of phosphorus in lake sediments have been increasingly investigated and its potential bioavailability has met with growing interest. Methods for the fractionation of phosphorus have been well documented (Pettersson et al., 1988; Psenner, 1988; Ruttenberg, 1992; Barbanti, 1994). In view of the potential importance of the bioavailability of phosphorus 
accumulated in surficial sediments, we reviewed the available literature on chemical extractable phosphorus and analysed bioavailability of phosphorus in sediments of West Lake and Lake Tai in China (NTB, 1996; Zhou and Zhu, 1999) and Lough Erne in Northern Ireland (Gibson, 1998).

\section{Materials and methods}

Surface sediment samples $(0-10 \mathrm{~cm})$ were taken from the centre of West Lake, the north-eastern part of Lake Tai near Wuxi and Suzhou, the southern part of Lake Tai near Huzhou using a mesh scoop and three sites in Lough Erne (routine stations 1-3) using a van Veen grab. Samples were stored at $4^{\circ} \mathrm{C}$ in a refrigerator.

Approximately $5 \mathrm{~g}$ of wet sediment samples were accurately weighed $\left(W_{1}\right)$ and then air dried in the air at room temperature. After 2 weeks, the loss in weight was determined $\left(W_{2}\right)$. The moisture content $\left(M_{\mathrm{c}}, \%\right)$ was thus calculated as follows

$M_{\mathrm{c}}=\left(W_{2} / W_{1}\right) \times 100$.

\section{1. $T P$}

Air-dry samples were digested with potassium persulphate and $30 \% \mathrm{v} / \mathrm{v}$ sulphuric acid, then $\mathrm{P}$ was determined using the acidic molybdate-ascorbic acid (AMAA) method (Murphy and Riley, 1962).

According to the literature, chemical extractable phosphorus that is closely related to bioavailability of phosphorus in lake sediments includes water-soluble phosphorus (WSP), readily desorbable phosphorus (RDP), algal available phosphorus (AAP) and $\mathrm{NaHCO}_{3}$ extractable phosphorus (Olsen-P). Their analytical procedures were as follows.

\section{2. $W S P$}

$1.0 \mathrm{~g}$ of wet sediment was placed into bottles, then the samples were shaken in $100 \mathrm{ml}$ of deionized water for 2.0 $\mathrm{h}$ on a reciprocating shaker at $150 \mathrm{rev} \mathrm{min}^{-1}$ and $25^{\circ} \mathrm{C}$. The suspensions were filtered through $0.45 \mu \mathrm{m}$ pore size membrane filter and the filtrates analysed for WSP using the AMAA method (Friend and Birch, 1960; Andrieux and Aminot, 1997; Psenner et al., 1985; Psenner, 1988).

\section{3. $R D P$}

$2.00 \mathrm{~g}$ of wet sediment was placed into bottles, then the samples were shaken for $1.0 \mathrm{~h}$ with $50 \mathrm{ml}$ of $0.01 \mathrm{~mol}$ $1^{-1} \mathrm{CaCl}_{2}$ solution, in a wet sediment to extracting solution ratio $1-25$. The suspensions were filtered through $0.45 \mu \mathrm{m}$ pore size membrane filter and the filtrates were analysed for RDP using the AMAA method (Reddy et al., 1980).

\section{4. $A A P$}

$0.80 \mathrm{~g}$ of wet sediment was placed in bottles and 200 $\mathrm{ml}$ of $0.1 \mathrm{~mol}^{-1} \mathrm{NaOH}$ solution (wet sediment to extracting solution ratio 1-250) were added into bottles, the bottles were covered and the samples were shaken for $4.0 \mathrm{~h}$ on a shaker. The suspensions were filtered and the filtrates were analysed for AAP using the AMAA method (Dorich et al., 1984, 1985).

\subsection{Olsen-P}

$2.50 \mathrm{~g}$ of wet sediments were placed in bottles, the samples were shaken for $0.5 \mathrm{~h}$ with $50 \mathrm{ml}$ of $0.5 \mathrm{M}$ $\mathrm{NaHCO}_{3}$ solution ( $\mathrm{pH}$ 8.5), in a wet sediment to extracting solution ratio $1-20$. The suspensions were filtered through $0.45 \mu \mathrm{m}$ pore size membrane filter and the filtrates were analysed for Olsen-P using the AMAA method (Olsen et al., 1954; Gonsiorczyk et al., 1998). The analytical results were normalised to air-dry weight $\left[\mathrm{P}_{\mathrm{f}}(\mathrm{dw})\right]$ according to the following formula:

$\mathrm{P}_{\mathrm{f}}(\mathrm{dw})=\mathrm{P}_{\mathrm{f}}(\mathrm{ww}) /\left(1-M_{\mathrm{c}} / 100\right)$.

\subsection{Sample sites}

The lakes are all of significance in the context of eutrophication. Lake Tai (Table 1) is a large, very shallow lake in the Yangtze valley, $90 \mathrm{~km}$ from Shanghai and subject to severe blooms of cyanobacteria. West Lake is smaller, highly prized for its scenic beauty in the city of Hangzhou. It is also thought to be under threat from eutrophication. Lough Erne is a large lake by

Table 1

Geographic and limnological features of the three lakes

\begin{tabular}{llll}
\hline & Lake Tai & West Lake & Lough Erne \\
\hline Position & $31^{\circ} 15^{\prime} \mathrm{N} 120^{\circ} 15^{\prime} \mathrm{E}$ & $30^{\circ} 18^{\prime} \mathrm{N} 120^{\circ} 10^{\prime} \mathrm{E}$ & $54^{\circ} 30^{\prime} \mathrm{N} 7^{\circ} 50^{\prime} \mathrm{W}$ \\
Surface area $\left(\mathrm{km}^{2}\right)$ & 2440 & 5.8 & 109.5 \\
Mean depth $(\mathrm{m})$ & 3.0 & 1.5 & 11.9 \\
$\mathrm{TP}\left(\mathrm{mg} \mathrm{m}^{-3}\right)$ & 45 & 62 & 59 \\
\hline
\end{tabular}


European standards although its area does not approach that of Lake Tai. In recent years, it has been subject to $\mathrm{P}$ enrichment from diffuse sources.

\section{Results and discussion}

The moisture contents in sediments from the three lakes are listed in Table 2. There were considerable differences between lakes, especially Lake Tai that had a much lower moisture content than either West Lake or Lough Erne.

TP content also showed a considerable range among sediments of the three lakes. The two lakes of China were between 600 and $1000 \mathrm{mg} \mathrm{P} \mathrm{kg}{ }^{-1} \mathrm{dw}$ (Table 2). Lough Erne sediments were richer in $\mathrm{P}$, containing between 2400 and $3000 \mathrm{mg} \mathrm{P} \mathrm{kg}^{-1} \mathrm{dw}$ (Table 2). In spite of the difference between the sediment $P$ contents, the mean TP in the lake water (Table 1) was little different between all three lakes, all of which would be classed as eutrophic on this basis.

Phosphorus in sediments can be considered as nonavailable, potentially available and immediately available (Hesse, 1971). Immediately available phosphorus in sediments of lakes means the most accessible form of phosphorus to algae, which equates to soluble inorganic phosphorus and almost exclusively orthophosphate (Bartsch, 1972). WSP is thus sometimes favoured as being the best estimate of bioavailable phosphorus (Hesse, 1971; Psenner et al., 1985).

Extraction with de-ionised water suggested that WSP was highest in the sediments of Lough Erne, between
153.0 and $202.2 \mathrm{mg} \mathrm{P} \mathrm{kg}^{-1} \mathrm{dw}$; $2-10$ times as much as that of the two lakes in China (Table 2). In the sediments of the two Chinese lakes, West Lake sediment contained twice as much WSP as Lake Tai sediments.

Except for the north-eastern part of Lake Tai, the sequence of WSP was consistent with that of TP and there was a significant correlation between WSP and TP in sediments of all three lakes. Regression analysis yielded the following equation:

$\mathrm{WSP}=0.0692 \mathrm{TP}-8.6 \quad\left(R^{2}=0.927, n=6\right)$.

The proportion of WSP to TP for the three lakes was different (Table 3). However, values for different sites in the same lake were similar. In Lough Erne, WSP comprised $6.4-6.7 \%$ of TP. In Lake Tai, WSP accounted for $3.4 \%$ of TP.

Some sediment $\mathrm{P}$ can be easily desorbed and released, particularly when the concentration of phosphorus in water column is depleted. In order to express the available form of phosphorus from sediments, the concept of readily desorbable phosphorus was also introduced. Neutral salt solutions can be better extractants of phosphorus than water (Elrashidi and Larsen, 1978; Reddy et al., 1980). Extraction by $0.01 \mathrm{M} \mathrm{CaCl}_{2}$ solution gave the highest values from Lough Erne, up to $67.2-89.7 \mathrm{mg} \mathrm{P}$ $\mathrm{kg}^{-1} \mathrm{dw}$ (Table 2), although much less phosphorus was extracted than in the WSP. Noticeably, RDP in West Lake was also high, 5.8-8.5 times as much as that in Lake Tai, although TP was similar in the sediments of the two lakes.

The RDP fraction was the smallest of the extracted phosphorus fractions in all three lakes. In particular, RDP in sediments of Lake Tai only accounted for

Table 2

Moisture content and TP and extractable P concentrations $\left(\mathrm{mg} \mathrm{km}^{-2}\right)$ in the sediments

\begin{tabular}{|c|c|c|c|c|c|c|}
\hline \multirow{2}{*}{$\begin{array}{l}\text { Name of lake } \\
\text { Sampling site }\end{array}$} & \multirow{2}{*}{$\begin{array}{l}\text { West Lake } \\
\text { Centre }\end{array}$} & \multicolumn{2}{|l|}{ Lake Tai } & \multicolumn{3}{|c|}{ Lough Erne } \\
\hline & & Northeast & South & Site 1 & Site 2 & Site 3 \\
\hline $\begin{array}{l}\text { Moisture content } \\
(\%)\end{array}$ & 80.9 & 48.4 & 42.5 & 74.3 & 72.2 & 70.3 \\
\hline $\mathrm{TP}$ & 700 & 1000 & 600 & 2800 & 3000 & 2400 \\
\hline WSP & 77.1 & 34.0 & 20.1 & 188.4 & 202.0 & 153.0 \\
\hline AAP & 354.1 & 171.0 & 103.5 & 1293.9 & 1331.2 & 1012.8 \\
\hline RDP & 44.8 & 7.7 & 5.3 & 67.2 & 89.7 & 70.2 \\
\hline Olsen-P & 238.9 & 174.3 & 85.0 & 512.2 & 672.3 & 521.3 \\
\hline
\end{tabular}

Table 3

Percentage of TP extracted by different procedures

\begin{tabular}{|c|c|c|c|c|c|c|}
\hline \multirow{2}{*}{$\begin{array}{l}\text { Name of lake } \\
\text { Sampling site }\end{array}$} & \multirow{2}{*}{$\begin{array}{l}\text { West Lake } \\
\text { Centre }\end{array}$} & \multicolumn{2}{|l|}{ Lake Tai } & \multicolumn{3}{|c|}{ Lough Erne } \\
\hline & & Northeast & South & Site 1 & Site 2 & Site 3 \\
\hline WSP & 11.0 & 3.4 & 3.4 & 6.7 & 6.7 & 6.4 \\
\hline AAP & 50.6 & 17.1 & 17.3 & 46.3 & 44.4 & 42.2 \\
\hline RDP & 6.4 & 0.77 & 0.88 & 2.4 & 3.0 & 2.9 \\
\hline Olsen-P & 34.1 & 17.4 & 14.2 & 18.3 & 22.4 & 21.7 \\
\hline
\end{tabular}


$0.8-0.9 \%$ of TP (Table 3). The proportion of RDP to TP in sediments from different sites of the same lake was close to one another. The correlation between RDP and TP was poorer than in any other analysis, but still highly significant $(P<0.02)$. The regression equation was as follows:

$$
\mathrm{RDP}=0.0279 \mathrm{TP}-1.3 \quad\left(R^{2}=0.78, n=6\right)
$$

Friend and Birch (1960) examined 10 different extracting methods for available phosphorus in soils and found that of these, only total organic phosphorus and inorganic phosphorus removed by hot $0.1 \mathrm{M} \mathrm{NaOH}$ were significantly related to crop response. Dorich et al. (1984) also found that $0.1 \mathrm{M} \mathrm{NaOH}$ extractable phosphorus was significantly correlated with 2-day and 14day available phosphorus for an alga (Selenastrum capricornutum). They suggested that $\mathrm{NaOH}$-extractable phosphorus can be used to estimate both short-term and long-term available phosphorus in sediments and is a measure of AAP.

As for the other methods, AAP in the sediments of Lough Erne was quite high, making up $46 \%$ of TP (Table 3). In the two lakes in China, AAP in West Lake was 2-3 times greater than in Lake Tai (Table 2) and the proportion of AAP to TP in sediments of West Lake was much higher than that of Lake Tai.

Although the proportion of AAP to TP in sediments of the three lakes differed greatly, the regression analysis shown that there was a good correlation between AAP and TP in sediments giving the equation:

$$
\mathrm{AAP}=0.504 \mathrm{TP}-170.9 \quad\left(R^{2}=0.962, n=6\right) .
$$

Olsen-P is a good index to represent the status of nutrients in soils (Heckrath et al., 1995). According to the index system of the UK Agricultural Development and Advisory Service (ADAS), Olsen-P concentrations in soils $>46 \mathrm{mg} \mathrm{P} \mathrm{kg}^{-1} \mathrm{dw}$ indicate a high nutrient status (MAFF, 1991). Thus, Olsen-P can be also regarded as a quantitative index of available phosphorus for algae to a certain extent. The data show that by the standards of agricultural soils, all the lakes had high Olsen-P (Table 2). In particular, Olsen-P in sediments of Lough Erne was an order of magnitude higher than the value used to indicate a high nutrient status in soils. The proportion of Olsen-P to TP in sediments of the three lakes was the most consistent of all the extractions used (Table 3). The regression equation was:

Olsen-P $=0.204 \mathrm{TP}+10.8 \quad\left(R^{2}=0.930, n=6\right)$.

\section{Conclusions}

Fig. 1 shows clearly the relative efficiencies of the four methods at extracting soluble phosphorus from the

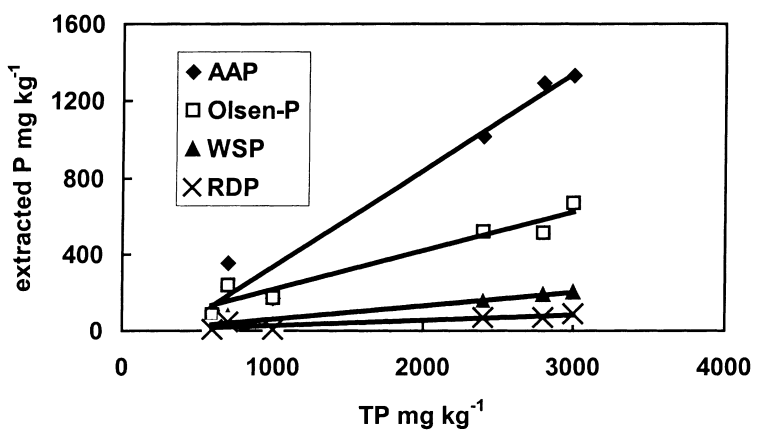

Fig. 1. Relationships between extracted phosphorus and TP in the different extraction procedures.

different lake sediments. The sediments from the three lakes differed widely in their properties, not least in their $\mathrm{P}$ contents, which did not seem to relate to the TP content of the lake water. Nevertheless, the rank order of the different $\mathrm{P}$ extracts was the same in all cases. AAP extracted the most phosphorus, followed by Olsen-P, WSP and RDP. In the lake situation, the actual release of phosphorus from lake sediments is governed not only by the reservoir of exchangeable phosphorus but by other factors such as $\mathrm{pH}$, redox potential and bioturbation (Zhou, 1995). WSP is probably the closest simulation of the lake situation but the close intercorrelation between methods suggests that comparing lake sediments on the basis of different extraction procedures will lead to similar conclusions.

\section{Acknowledgements}

This research was a component part of the UKChina link project (Ref. No. SHA/992/297) which was financially supported by the British Council office in Shanghai and the Open Laboratory on Material Cycles in the Pedosphere in Nanjing (approached No. 971532). The authors wish to thank Mr. B.M. Stewart and Mr. M. Lyons for their assistance in chemical analyses.

\section{References}

Andrieux, F., Aminot, A., 1997. A two-year survey of phosphorus speciation in sediments of the Bay of Seine (France). Continental Shelf Research 17, 1229-1245.

Barbanti, A., 1994. Critical aspect of sedimentary phosphorus chemical fractionation. Journal of Environmental Quality 23, 1093-1102.

Bartsch, A.F., 1972. Role of Phosphorus in Eutrophication. USEPA, Office of Research and Monitoring, Washington, DC, EPA-R3-72-001, 45 pp.

Chang, S.C., Jackson, M.L., 1957. Fractionation of soil phosphorus. Soil Science 84, 133-144. 
Dorich, R.A., Nelson, D.W., Sommers, L.E., 1984. Availability of phosphorus to algae from eroded soil fractions. Agriculture, Ecosystems and Environment 11, 253-264.

Dorich, R.A., Nelson, D.W., Sommers, L.E., 1985. Estimating phosphorus in suspended sediments by chemical extraction. Journal of Environmental Quality 14, 400-405.

Elrashidi, M.A., Larsen, S., 1978. The effect of phosphate addition on the solubility of phosphate in soil. Plant and Soil 50, 585-596.

Friend, M.T., Birch, H.F., 1960. Phosphate responses in relation to soil tests and organic phosphorus. Journal of Agricultural Science 54, 341-346.

Gibson, C.E., 1971. Nutrient limitation. Journal of Water Pollution Control Federation 43, 2436-2440.

Gibson, C.E., 1997. The dynamics of phosphorus in freshwater and marine environments. In: Tunney, H. et al. (Eds.), Phosphorus Loss from Soil to Water. CAB International, Oxon, pp. 121-144.

Gibson, C.E., 1998. Lough Erne. In: Moriarty, C. (Ed.), Studies of Irish Lakes and Rivers. Marine Institute, Dublin, pp. 64 72.

Gonsiorczyk, T., Casper, P., Koschel, R., 1998. Phosphorusbinding forms in the sediment of an oligotrophic and a eutrophic hardwater lake of the Baltic lake district (Germany). Water Science and Technology 37, 51-58.

Heckrath, G., Brookes, P.C., Poulton, P.R., Goulding, K.W.T., 1995. Phosphorus leaching from soils containing different phosphorus concentrations in the Broadbalk Experiment. Journal of Environmental Quality 24, 904-910.

Hesse, P.R. (Ed.), 1971. A Textbook of Soil Chemical Analysis. John Murray, London, pp. 255-300.

MAFF (UK Ministry of Agriculture Fisheries and Food), 1991. Fertilizer Recommendations for Agricultural and Horticultural Crops. Reference Book 209. MAFF, HMSO, London, UK.

Murphy, J., Riley, J.P., 1962. A modified single solution method for the determination of phosphate in natural water. Analytica Chimica Acta 27, 31-36.

NTB (National Tourism Bureau of China), 1996. Atlas of the People's Republic of China. Beijing, Cartography Press.
Olsen, S.R., Cole, C.V., Watanabe, F.S., Dean, L.A., 1954. Estimation of available phosphorus in soils by extraction with sodium bicarbonate. In: USDA Circular. USDA, Washington, DC, p. 939.

Pettersson, K., Boström, B., Jacobsen, O.S., 1988. Phosphorus in sediments - speciation and analysis. Hydrobiologia 170, 91-101.

Psenner, R., 1988. Fractionation of phosphorus in suspended matter and sediment. Ergebnisse der Limnologie 30, 98-113.

Psenner, R., Pucsko, R., Sager, M., 1985. Fraktionierung organischer und anorganischer Phosphorverbindungen von Sedimenten. Versuch einer Definition ökologisch wichtiger Fraktionen. Archiv für Hydrobiologie Supplement 70, 111115.

Reddy, K.R., Overcash, M.R., Khaled, R., Westerman, P.W., 1980. Phosphorus adsorption-desorption characteristics of two soils utilized for disposal of animal wastes. Journal of Environmental Quality 9, 86-92.

Ruttenberg, K.C., 1992. Development of a sequential extraction method for different forms of phosphorus in marine sediments. Limnology and Oceanography 37, 1460-1482.

Williams, J.D., Syers, J.K., Armstrong, D.E., Harris, F., 1971. Fractionation of inorganic phosphate in calcareous lake sediments. Proceedings of the Soil Science Society of America 35, 250-255.

Williams, J.D., Syers, J.K., Walter, T.W., 1967. Fractionation of soil inorganic phosphate by a modification of the Chang and Jackson procedure. Proceedings of the Soil Science Society of America 31, 736-739.

Williams, J.D.H., Jaquet, J.-M., Thomas, R.L., 1976. Forms of phosphorus in surficial sediments of Lake Erie. Journal of the Fisheries Research Board of Canada 33, 413-429.

Zhou, Q., 1995. Ecology of Combined Pollution. China Environmental Science Press, Beijing.

Zhou, Q., Zhu, Y., 1999. Simulated studies on degradation of organic matter and release of $\mathrm{CO}_{2}$ and $\mathrm{CH}_{4}$ in sediment from the West Lake under various oxygen-supply conditions. Acta Scientiae Circumstantiae 19, 11-15. 